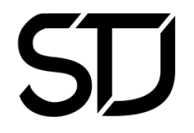

\title{
Twelve theses on the place of Christian theology in multi-disciplinary conversations ${ }^{1}$
}

\author{
Conradie, Ernst \\ University of the Western Cape \\ econradie@uwc.ac.za
}

I dare to offer the following reflections on the place of Christian theology in multi-disciplinary conversations in order to invite further reflection.

1. Christian theology, in conversation with numerous other disciplines (the various sciences, history, philosophy and the arts), each with their distinct focus, participate in a common task of sense making (Brian O'Connell) - helping the societies in which we are situated to understand the world in which we find ourselves, analysing what has gone wrong, and helping societies to respond to contemporary challenges.

2. From the perspective of other disciplines, Christian theology may well be understood as a particular school of thought (a "philosophy"), a way of looking at the world in which we find ourselves, one that is guided by some core assumptions (as is the case in other philosophical schools), that may help to illuminate some dimensions of reality but will inevitably distort others. There should be room for such perspectives at the table of multi-disciplinary conversations (Wentzel van Huyssteen), especially given the influence of various forms of Christianity in shaping the world, for the better but also for the worse.

3. This common task of sense making is one in which Christian theology can make a substantive but rather limited contribution. On intra-theological terms this common task is one of understanding

1 Conference on “Theology on the edge", Stellenbosch, 3-5 September 2014 
the "whole revelation of God" (Herman Bavinck). The substantive contribution that Christian theology can make is to approach this common task of making sense of the world around us on the highly particular basis of God's revelation in Jesus Christ through the Spirit (see below). This contribution remains limited in the sense that it would not do to offer soteriological answers to ontological questions (Arnold van Ruler). The task of "philosophy" (in the broader sense of the term) is therefore much wider than that of Christian theology (again Bavinck). When it comes to ontological questions on what the world is like, Christian theology is a minor player amongst many others in the field.

4. On intra-theological terms the task of other disciplines is more important than its own task (crucial though that may be) - in the same way that the church does not exist for its own sake but for the sake of the well-being of the whole world - where the reign of God is to come. We do not become human in order to become Christians; we need to become Christians in order to be human again (Dietrich Bonhoeffer, also John de Gruchy). On this basis Christians belong to the world (shared with other creatures) before they belong to the church (again Bonhoeffer on Christian worldliness).

5. In this common task of making sense of the world in which we find ourselves, Christian theologians may well be asked to explain what they bring to the table that is distinctive. Such explanations (or public translations - Heinrich Bedford-Strohm) may be offered in non-theological categories albeit with the proviso that the danger be heeded of fitting Christianity under some other umbrella concept (religion, spirituality, civil society) - and in the process translating it into something less than what it is (as Karl Barth might say). The Christian faith is not unrelated to such categories, one may say, primarily because the triune God is confessed to be not unrelated to the world in which we live. In order to avoid a reductionist and selfsecularising approach (Wolfgang Huber), one may say that Christian faith, hope and love employs a wider, more encompassing lens to offer a Christian view of the world as a whole. This is one that brings into play not only the social construction of reality (Peter Berger) but also constructions of ultimate reality (Paul Tillich and others). 
This requires a non-reductionist recognition of various forms of transcendence (George Ellis and others). Notions of transcendence and of ultimate reality are necessarily socially constructed, typically very particular and therefore form part of immanent reality (Klaus Nürnberger and others). However, if this entails nothing but a social construction, it is a construction of nothing less than that, which is ultimate. What is truly ultimate cannot be captured under another umbrella. It is also not possible to juxtapose two or more versions of the ultimate since that would by definition challenge the ultimate status of each. At the same time, what is truly ultimate will necessarily remain an ultimate mystery. Christian theology therefore need not and cannot avoid speaking about God, precisely in conversation with other disciplines. What is immanent is discovered and appreciated only through the emergence of notions of transcendence. It is only in reaching the edge that the centre can be recognised.

6. While it is possible to offer $a$ Christian view of the world (e.g. redescribing and ascribing it as the household of the triune God), it is impossible to develop a comprehensive Christian worldview (contra neo-Calvinist views) governing all aspects of reality if this is to be a re-description of the world as we experience it and know it also through other disciplines. Any discussion of worldviews (whether in the context of African traditional worldviews, neo-Calvinism, ecological discourse, the sociology of knowledge or the philosophy of science) should heed the reminder that it is impossible to view the world as such (or to adopt a "holistic" perspective). Nevertheless, religious constructions of ultimate reality cannot be reduced in sociological terms to a set of relationships or in ethical terms to a way of being in the world.

7. In a Christian context the "social construction of ultimate reality" (a term that is best used with hesitation) is approached on the basis of highly particular clues to the ultimate mystery of the world (Eberhard Jüngel). For Christians, the best available set of clues to that mystery is found in the ministry, death and resurrection of Jesus the Christ (others would find such clues elsewhere). The mystery of the world is expressed in the core conviction that the world belongs to the triune 
Creator, that the world is the household of God. The cosmic scope of this conviction needs to be rediscovered again and anew in highly particular contexts and conversations. Each place may thus become the centre of the universe. The set of clues that Christians have found may provide a sense of orientation and direction for an on-going journey, but remains nothing more than a clue to a mystery that ultimately cannot be fathomed. At best we are led into that mystery (John de Gruchy). This suggests the need for apophatic theology but also indicates the limits of the common attempt at making sense of the world in which we find ourselves.

8. A Christian way of looking at the world around us (e.g. seeing it as the triune God's household) is scandalously counter-intuitive, is typically offered polemically and critically (Oepke Noordmans), and yet may offer profound insights in conversation with other perspectives. It may be contrasted with "warped" views of nature (Howard Snyder), for example in terms of a romanticised and all too leisured sense of beauty, one-sided Darwinian views on nature as "red in tooth and claw", capitalist views on land as nothing but real estate and pantheist views on nature as something so sublime that it ought to be worshipped. It makes a difference to see a piece of land as nothing but a toxic rubbish dump or seeing it nevertheless as God's own garden. In the human sphere it makes a huge difference to see the victims of history (and the perpetrators too!) as part of God's family (Desmond Tutu). Accordingly, the beggar at the door is nothing but my brother, the prostitute on the road my sister and the rapist my uncle. One may argue that the radical inclusivity of Jesus' Galilean ministry is one of the distinguishing features of Christianity. It is radical because it calls upon those who are themselves excluded to include others in the household of God whom they may prefer to have excluded. Remarkably, the victims of history are called to conversion in order to see God's magnanimous grace. The genius of Paul's ministry was to recognise that this message is not restricted to Galilee of Palestine but has equally radical implications for the inclusion of Gentiles. This disturbing inclusivity is being rediscovered in different contexts. For example, the vision that the whole household of God includes all 
other forms of life is being discerned amidst contemporary economic injustice, various forms of violence and environmental destruction.

9. The plausibility of a Christian way of looking at the world and of what's wrong in the world is undermined (for outsiders and insiders alike) whenever there is too much cognitive dissonance with what people otherwise know, believe to be the case and deem to be valuable. This requires sufficient "traction" between Christian beliefs and insights emerging from other disciplines (Philip Clayton). Such traction does not imply verification or falsification but there needs to be at least some congruence if Christian theology is to contribute to the common task of sense-making, if the perspectives it offers can indeed help to make sense of such insights, to help others to see what would otherwise not be recognised. The need to examine the plausibility of the Christian faith (i.e. from the perspective of insights emerging from other disciplines) is also important for the sake of the Christian faith, namely to remove false (intellectual) stumbling blocks so that the true scandal of its core message may be communicated as clearly as possible.

10. It would be inappropriate to take theological short cuts to introduce revealed truths into multi-disciplinary debates. For example, it is inappropriate to offer an a priori (revealed) diagnosis of the malaise of the human condition, or to analyse the triple problem of poverty, unemployment and inequality, or to uncover the root causes of environmental destruction) before the "patient" is properly examined. The task of sense making is an on-going one that has to take into account changing circumstances (reading the signs of the time), emerging knowledge, new insights and other relevant (philosophical) perspectives. The (limited) contribution that Christian theology can make to inter-disciplinary conversations cannot be made in advance, before such conversations take place.

11. The lens that is employed in Christian contributions to the common task of sense making may be valuable for other disciplines in a real but limited way besides the particular perspectives that Christian contributions bring to the table. The mere presence and persistent 
participation of theologians may sometimes help to emphasise the significance of particular issues on a common agenda.

12. Given the "wider lens" that is employed, theologians together with philosophers and scholars of religion, may help to recognise, analyse and critique the most basic assumptions embedded in various schools of thought in other disciplines. For example, the vocabulary developed in the Christian tradition can aid the common task of offering a diagnosis of what is wrong in the world. In addition, the Christian tradition may facilitate sensitivity for the moral visions, goals, values and rules that are embedded in research programmes in other disciplines. Such contributions may not always be significant and may therefore not be valued, but to ignore such sensitivities would be to the detriment of any other discipline in the long run.

\section{A Brief Response to Ernst Conradie's Twelve Theses}

\section{Van Huyssteen, J Wentzel}

University of Stellenbosch

wentzel.vanhuyssteen@ptsem.edu

Over against reductionist, overtly ideological views that place the sciences and theology on a direct collision course, I have argued, like Ernst Conradie, for more nuanced and multidimensional approaches to interdisciplinary dialogue that take seriously the contextual, social, and historical dimensions of both the sciences and theology (and specifically, Christian theology). This multidimensional approach means that any interdisciplinary dialogue between the scientific and theological reflection should not only be grounded in contextual and historical studies of the actual practices of scientific and religious belief, but also focus on the actual real-life scientist(s) or theologian(s) who are venturing forth into the risky waters of interdisciplinary dialogue.

I have argued specifically for a public Christian theology that is defined by the responsibility to engage in public discourse, and that can access this level of public engagement only through a carefully crafted model for interdisciplinary reflection (cf. van Huyssteen 1999; 2006). In the kind of multi-dimensional, integrative interdisciplinary conversation that I argue 
for, terms like interdisciplinarity and contextuality take centre stage, and have the value of identifying shared concerns and points of agreement, and maybe more importantly, of exposing areas of disagreement and putting into perspective a methodology for also discussing specific divisive issues. We also need to keep in mind that in any interdisciplinary conversation different discourses often represent radically diverse perspectives, and also different and distinct methods of investigation, which mean they cannot be reduced to each other or derived from each other. Unlike Conradie, I would therefore talk about the specific disciplinary focus of theology and not so much about its 'limited' contribution, or being a 'minor player' in the field (cf. Thesis 3).

Conradie does correctly state his central view that theology shares a common task of sense making with other disciplines and in that sense can make substantial contributions to the interdisciplinary dialogue. I found it somewhat confusing, however, that Conradie would specify these contributions, one the one hand, in metaphysical terms like 'ultimate reality', but at the same time, and correctly, can state that the common task of making sense of the world is on the highly particular basis of God's revelation in Jesus Christ. On my view theology would be a 'minor player' only if, on the one hand, it does not take part in fundamental interdisciplinary questions shaped by, for instance, the reality of evolution, or, on the other hand, lose itself in metaphysial trimmings like 'absolute realities'. And on another point: the methodological move to posit highly specific theological constructs like 'the triune God' as a 'top down' departure point for the interdisciplinary conversation is problematical if not hermeneutically interpreted, epistemologically explained, and contextually developed for a specific Christian theology. Exactly at this point it is important to notice Conradie's own suggestion for the need for a more apophatic theology (Thesis 7). This indeed indicates the epistemic limits of the common attempt at making sense of the world, but it does not make theology into a 'minor player'.

Finally, in any interdisciplinary conversation it is extremely important the realize that theology also is, first and foremost, all about conceptual problem-solving, and that it is in this analogical given that all the various disciplines find an epistemological commonality. These problem-solving judgements apply to both theology and the sciences as we use the same 
kinds of interpretative and evaluative procedures to understand nature, humans, and the social and religious/theological dimensions of our lives. This can also enable us to identify possible shared conceptual problems as we negotiate the porous boundaries between our different disciplines.

\title{
Engaging Conradie's theses
}

\author{
Loubser, Gys \\ University of Pretoria \\ gysloubser@gmail.com
}

Conradie's twelve theses form a concise and dense text that aims to engage a wide range of conversations between theologians and other scientists. It reads like a mission statement in which he addresses the characteristics and focus of such conversations, whilst providing rules of conduct. With these theses Conradie calls upon Christian theologians to acknowledge that while their contributions to these conversations are valuable, they are also limited. But why state the limited nature of contributions by Christian theologians?

Firstly, Conradie intends to instil trust amongst other scientists by agreeing that Christian theologians will not overestimate their contributions by imposing meta-perspectives over and above perspectives from other scientists. However, Christian theologians also expect that the same courtesy will be shown toward them. This means that all contributions are limited.

Secondly, Christian theologians' knowledge is limited and other scientists can assist them in clarifying and broadening their knowledge. This is true for all participants, which means all contributions are limited.

Lastly, it is important to acknowledge that Christian theologians draw on particular core assumptions in developing their understanding and approach to reality. This is not unique to Christian theologians as all participants in the multidisciplinary conversation draw on their own unique set of core assumptions. The limited nature of contributions to the multidisciplinary conversation is a limitation shared by all who are dedicated to "...helping the societies in which we are situated to understand 
the world in which we find ourselves, analysing what has gone wrong, and helping societies to respond to contemporary challenges (Thesis 1)."

However, perhaps we should reflect more on the disciplinary fragmentation that is the source of these conversational limitations. If the major societal problems are the result of the difference between how life works and the way we think (Gregory Bateson), is it not rather our assumptions that actually limit us?

\title{
At the table of multi-disciplinary conversations
}

\author{
Veldsman, Daniël \\ University of Pretoria \\ danie.veldsman@up.ac.za
}

More fundamental to and preceding the participation by Christian Theologians in a common task of sense making (see Conradie 1), is an understanding of Christian Theology's role as being a "conversation specialist" (Will Storrar) in the context of the science-religion / theology discourses and as being a "conversation partner" on the genesis of knowledge (that is, on models of rationality). As "conversation partner", Christian Theology must listen to the dialogue partners, participate in and engagingly contribute to the science of philosophy's discourses on models of rationality in formulating criteria for making knowledge claims. On these knowledge claims, Christian Theology has no monopoly. It can neither prematurely accept an (self-introduced) designation such as "a particular school of thought" (see Conradie 2 and 11) as vantage point nor prematurely introduce "revelational claims" (see Conradie 3 and 10) as immunisation strategy. Christian theologians indeed may be asked to explain what they bring to the table that is distinctive (see rightly so Conradie 4) for them as "conversation specialists". Let me formulate and substantiate my argument in response to Conradie only with specific reference to two issues. Firstly to the welcoming, seating and conversation at the table. This table Conradie (see 2) calls - in reference to Van Huyssteen - the table of multi-disciplinary conversations. And secondly Conradie's statement on the substantive contribution that Christian Theology can make in taking on the common 
task of understanding the "whole revelation of God". I restrict my response to these two issues.

1. To spontaneously choose within the exciting contemporary and wideranging philosophical discourses but one example: Paul Ricoeur's specific understanding of an a-religious concept of revelation as welcoming address, and within the context of an understanding of creation (nature) as God's "epistle to humanity", it is clear that a concept of revelation is acknowledged as being constitutive for Christian theological reflection. How can it be re-imagined within science-theology discourses?

2. If it in its most simplified definition means "to uncover / to make known something which was previously unknown", and in the context of Christian theology, "God's self-revelation" then surely it implies some kind or form of knowledge claims.

3. If such theological knowledge claims wishes to maintain its identity without retreating to an esoteric world of private, insular knowledge claims, it should consciously seat itself at the interdisciplinary table of reflection on the genesis of knowledge.

4. At the interdisciplinary table of reflection on the genesis of knowledge, theological reflection will find a justification for its reservation at the table, as well as pointers for making knowledge claims. The former, namely a justification for its reservation at the table, is announced by evolutionary epistemology. The latter, namely the pointers, are to be formulated in the interdisciplinary space that creatively opens up in the dialogue with evolutionary epistemology.

5. Regarding the justification for its reservation at the table, evolutionary epistemology as a theory of cognition, reveals the biological roots of all human rationality, and thus the shared resources of human rationality for both scientific and theological reflection. It subsequently opens space for an interdisciplinary account of our epistemic activities, and facilitates a post-foundationalist notion (Van Huyssteen) of rationality (that is, it takes us beyond traditional disciplinary boundaries). 
6. Regarding the formulation of pointers, theological reflection is made aware not only of being shaped by its cultural, social, historical contexts, but also by the biological roots of human rationality. However, theological reflection as cultural achievement, so intimately entwined with the process of biological evolution, is ultimately not determined by it. In the words of Keith Ward: it is designed to lead to levels of explanation and reality beyond itself.

7. If our genes do not completely determine our culture and our rational abilities, then it may be reasonable to expect that our genes, our culture, and our rational abilities may also not completely determine the enduring and persuasive need for metaphysics, and ultimately for life transforming religious faith. This awareness enables theological reflection to move beyond so called narrow options of either / or, that is for example of naturalism and supernaturalism.

8. This movement beyond so called narrow options is prompted by the shared focal interest (of scientific and theological reflection) on life processes, but is also interested in more since it is concerned with the interpretation of existence. In "more", since nature is not designed to answer all the metaphysical questions.

9. Regarding the "more", that is, the interpretation of existence, evolutionary epistemology tells us that some kind of metaphysics seems to be a general characteristic of all humans, and subsequently of the naturalness of religion, and of belief.

10. In religious belief we find a drive toward something transcending human powers as reflected in the fabric of the universe, a drive toward a reality greater that transcends empirical reality.

11. One of the theological lines which I consider to be fruitful to pursue for the interdisciplinary conversation is amongst others Ricoeur's focus on the poetic dimension of language (that is, the conjunction of mythos and mimesis), and the category of testimony which addresses our imagination.

12. The historical-poetical "Testament" (that is, Scripture and nature) can subsequently be re-imagined as an emerging "one book" (albeit differentiated with regard to "information") in the on-going 
process of evolution in which our ability for rational knowledge and humanity's endless quest for ultimate meaning finds an existential village. Conradie (see 5-7) employs in this regard the formulation in a Christian context - with which I wholeheartedly agree - of the "social reconstruction of ultimate reality" from clues provided by the biblical documents on the historical-theological origin of Christianity and the social-ethical implications that interpretatively flow from these commitments (see Conradie 12).

13. Being "told" what God is like, can thus unfold in very different (dazzling) manners: within life experiences and testimonies thereto, life processes, nature and its mind-boggling evolutionary history in all its diversity and fascinating readings.

14. Such a re-imagining of revelation is in my opinion not only to be understood as celebrating the mystery of the "revealed God", but also as an acknowledgment in a credible manner of the depth, width and height of that very mystery that sustains humanity as imago Dei. 